\title{
IN SEARCH FOR CANON OF SINGAPORE MALAY POETRY: RFLECTION ON NATURE, RACE, RELIGION AND LOVE
}

\author{
Hadijah Rahmat \\ hadijah.rahmat@nie.edu.sg \\ Nanyang Technological University \\ Singapore
}

\begin{abstract}
This paper discusses selected poems by three generations of Malay writers in Singapore from the first generation poets who received their vernicular education during British colonial period, before Malayan Independence in 1957; to second generation writers who received Malay education when Singapore was part of Malaysia, 1957-1965 who established their poems in 1970s; and the third generation writers who received bilingual education who began to make impacts when Singapore become a Republic in 1980s. These iconic poems embody the easthetic as well as the cultural and political values of Malay society. It is an early attempt to define and search for canon of Singapore Malay poetry.
\end{abstract}

Keywords: literature, canon, poetry, Singapore, culture, identity, values

\section{INTRODUCTION}

Some years ago, I was asked by one of English literature professor to identify a few Malay poems written by Singapore Malay poets which can be regarded as canon. This has led me to reflect on the notions of literary canon and development of Malay poetry.

Modern Malay poetry has history for about a century since its birth of in early 20th century. However, Malay poetry written by the citizens of 
Singapore, of independent nation since 1965, is relatively young in age, of about 45 year olds. This period of time is rather short for any nation to develop its national identitities despite its economics has been developing very rapidly over a few generations. Singapore has inherited various great civilizations from Malay, Indian, Chinese and European worlds. Despite this, the process of formation of Singapore's national identity is still at its early stage, particularly in its cultures and arts.

Therefore, the task of selecting canon Malay poems and poems in other official languages is indeed challenging, especially when canon poem itself firstly must be of high standard of quality, sustainable, stable and is well tested in term of its influence and recognition from audience and its social contexts. Moreover, a literary work which had already been accepted as canon by a society, would be revisited and reevaluated due to changes in society and times.

This was the case for Western literature since 1960s when it was criticized as a collection of books written by "dead white European males" which are not representing the contemporary perspective of changed Western communities in all over the world. For example, Alan Bloom (1987), in his book, The Closing of the American Mind, has debunked the existing Western notion of canon of English literature in Europe and America. The contribution of non-white ethnic writers from African-Americans, Hispanic Americans, Asian Americans, Native Americans and non-European writers and female writers who write in English are now given due recognition as results of this literay debate and reevaluation. Literary works by feminist and gay authors which were never considered for canon works, have since been accepted and are now taught in some university courses.

The term "canon" was first used to refer to "the books of the Bible officially recognized by the Church"; and its meaning has changed and widen to include literary works that has achieved "official status" that is of high quality and high esthetic values (George P. Landow, 2010). The experience of Western literature shows that the concept of literary canon is not static but always changing. This is explained by O'Brien:

Canon is an evolving creation, not something written in stone

(Sean O’Brien, 2008)

Thus, what should be the definition of canon of poetry for Singapore? What are the criteria to be used to select poems by Singapore poets? 
The literary canon of a country or a group of people is comprised of a body of works that are highly valued by scholars and others because of their aesthetic value and because they embody the cultural and political values of that society

(Thomas J.Schoenberg \& Lawrence J.Trudeau, 2006) ${ }^{1}$

Here, the works selected must consist of two values-the aesthetical as well as cultural and political values of its society. Schoenberg and Trudeau have defined literary canon as "Best literary achievement of the culture". This definition recognizes the dynamics of literary and cultural processes and complexity of its meanings and significance. Hence, this definition is adopted as my working definition as it is most suitable and practical for selecting canon of Singapore Malay poetry.

\section{SELECTED POETS}

Since 1965 to date, thousands of poems have been written by Singapore Malay poets. ${ }^{2}$ The exact total numbers of poems produced within this period is unknown as no comprehensive studies on it have been done. Studies on Malay poems in Singapore are done by Masuri SN $(1983,1985)$, Hadijah Rahmat (1987, 2000, 2004) and by Rasiah Halil (2000).

In comparison to other genres, poetry is the most popular and productive genre. Thousands of poems have been written by numerous poets; however, out of these only 11 poets and 11 poems are selected. These poets have been active in writing at least for two decades within the period of 1965-2000. Their literary works are widely known within the literary fraternity and have received social recognition by the Malay Literary Awards in Singapore (Hadiah Sastera or Hadiah Persuratan). Some poets have been awarded national and regional literary awards such as Anugerah Tun Seri Lanang, the Cultural Medallion, Anugerah Mastera and SEA Write Awards. Apart from the literary awards, the stability and sustainability of the author and their works are also taken into consideration. The new writers who only appeared in the last 10 or recent years are not included, even though their works have shown some great potential. Stability and sustainability are critical criteria for this selection.

These poets are also representing three generations of Malay writers in Singapore: the early generation poets who received their vernacular education during British colonial period, before Malayan Independence in 1957 (such as Masuri SN, Suratman Markasan, A.Ghani Hamid and Noor 
SI) and they were active since 1950s and 1960s; the second generation writers who received Malay education when Singapore was part of Malaysia, 1957-1965 (such as Djamal Tukimin and Mohamad Latif Mohammad) who established their poems in 1970s; and the third generation writers who received bilingual education when Singapore becomes a Republic (Asmin, Rasiah Halil, Hadijah Rahmat, Johar Buang and Isa Kamari) who began to make impacts in 1980s. This representativeness of generation of writers and their iconic works is another criterion used in the selection apart from the poet's stability, sustainability and social recognition. These selection criteria have their weakness and may not be perfect, but they provide an objective, balance and best framework to work on within limited number of poets and space given to the editor.

\section{SELECTED POEMS}

\section{"Ini Nasi Yang Kusuap" (This Rice That I Eat)}

Since its beginning, Malay literature had emphasized on role of literature for development and welfare of society. The social function of traditional literature was continued by modern Malay writers, especially in 1950s, by a group of young writers from 1950's generation which called themselves ASAS 50 who upheld the motto of "Arts for Society" (Sastera Untuk Masyarakat). These ASAS 50 writers wanted to fight for political independence and were concerned about for the plight of the poors, the under class, such as the farmers, fishermen and labourers. The struggles and contributions of these working classes were highlighted and highly acknowledged. Masuri's poems are the best representation of this literary movement and new social views that emerged after the Second World War. Masuri's fighting spirit for the cause of the underclass was explicitly manifested in his poem, "Ini Nasi Yang Kusuap" (This Rice That I Eat), as a noble tribute to farmers who struggled in planting and harvesting the padi trees to provide rice or basic staple foods needed by the society.

Jadi yang kumakan bukan berasal dari nasi tapi peluh, darah dalam isi mengalir pasti. jadi yang kutelan bukan berasal dari padi tapi dari urat, dari nadi seluruh Pak Tani. 
(So what I eat is not originally from rice

but from sweat, blood constantly flowing;

so what I shallow is not originally from padi

but from the sinews, the pulse of all peasants.)

This poem was written before 1965, but it should be regarded as canon of Singapore, as it serves as a bridge and historical symbol that reflects the economic, cultural and political relationship between Singapore and Malaysia and other parts of Malay world before 1965. This poem is rather special because of its cultural and historical values, its universal message, and for its aesthetical value. This poem has established Masuri as a pioneer of modern Malay poetry. Interestingly, this poem continues to attract great interest among the younger generation. The poem is widely popular and being studied in schools in Singapore and Malaysia; and two songs have been composed based on this poetry. ${ }^{3}$

\section{"Jalan Permulaan" (The Beginning)}

Political developments and educational backgrounds significantly determined the development of Malay literature in Singapore. The authors are always sensitive and very concerned about the plight of their community due to Singapore's separation from Malaysia and the impacts of rapid urbanization and modernization which influenced their tradition, culture and identity. This social concern was clearly manifested in a poem, entitled "Jalan Permulaan" (The Beginning), written by a first generation writer named Suratman Markasan. The poet felt a deep sense of loss and expressed it repeatedly, six times in his poem:

Aku kehilangan lautku

Aku kehilangan bukitku

Aku kehilangan diriku.

Aku kehilangan beliaku

Aku kehilangan udara bersih

Aku kehilangan namaku.

(I've lost my sea

I've lost my hill

I've lost my soul. 
I've lost my youth

I've lost my clean air

I've lost my self.)

The poem was written in 1979 and described vividly the emotions of the Malay community who were relunctant and find it difficult to leave their life from kampung to flat houses. The poem ends with a sense of uncertainty and loss of identity, as the poet was not sure about the future of his community, even when he strongly felt that Singapore is truly his country:

Singapuraku

Aku mengerti sekali

Di sini tempatku

Tapi aku tidak tahu bila

Aku akan menemui segala kehilanganku?

(My Singapore

I do indeed understand

Here is my home

But I do not know when

I will regain what I have lost.)

This poem was selected to show the impact of resettlement or urbanization on the Malays presented in the international seminar, Britain and Malay World Symposia at Royal Asiatic Society London in $2007 .^{4}$

\section{“Melayuku Melayumu” (My Malayness Your Malayness)}

The plight and predicament of the Malays continue to attract the second generation of Malay poets, represented by Mohd Latiff Mohammed in his poem, "Melayuku, Melayumu" (My Malayness, Your Malayness):

Telah kutafsir makna Melayuku

Dari mata dan bibir sejarah

Yang luka bagai selendang berdarah

Yang pilu bagai perawan berduka

(I have deciphered the meaning of my Malayness

From the eyes and lips of history

That's wounded like a bloodied shawl

That's downhearted like a deflowered virgin) 
This poem presents two types of Malay lives-the Malayness of the poet "Melayuku" (My Malayness) and the Malayness of others "Melayumu "(Your Malayness). The interpretation of "Melayu" is rather ambigious. "Melayuku" could refer to the Malays in Singapore, while "Melayumu" might refer to the Malay societies beyond Singapore, such as the Malays in South East Asian region and beyond. It could also meant the Malays within similar geographical space, but are rather different in their perspective of life (the poet vs others).

In either interpretation, the poem conveys a darker side of feelings of the Malay community in Singapore, who suddenly become a minority after the separation of Singapore from Malaysia and they felt "marginalized", and suffered a great sense of loss because of economic backwardness and various stresses of modernization. This social frustration as alienated minority was expressed intensely by the poet. Their feelings were bitter and murky because of the dark contrasts between the two forms of Malayness:

Mengalirnya Melayumu

lembut dan terus

menjadi embun

dingin mempesona

(The flow your Malayness

soft and continuous

the dews become

cold and captivating)

Telah kujumpa Melayumu

berjebat dan bertuah

menggenggam tangan membuka dada

mematahkan bianglala

yang melilit pinggang sejarahmu

(I have met your Malayness

in Jebat and Tuah

gripping our hands opening our hearts

like a torn sash

which encircles the waist of history

at the edge of dawn with the distressing dream)

Apart from its social values, the strength of this poem is in its aesthetics. The poet has vividly and effectively employed nature as metaphors to describe 
the predicament of the Malays (Melayuku) as follows: "woeful wolf/hurt and tortured/in the belly of cave/dark as coal"; "stuck in mud/dusty and dirty" "hugged by the savaged city/caressed by the asphalt on the road"; and "a collapsed stage".

This poem is also popular and always been recited in numerous Malay language activities in Singapore. ${ }^{5}$

\section{"Udara" (Air)}

In addition to the social problems of their community, national issues are also touched in Malay poetry. For example, life in the cramped crowded city and stiff competition faced by the populations.

Dalam ruang terlalu sempit

Dihembus kembali

Dan setiap hembusan dipadati racunan

Bakal disedut lagi

Berulang dan terus berulang

Hingga pada saatnya

Ada terpaksa dan dipaksa

Untuk mencium bumi.

(In a space cramped too tightly

they breathe out again

and every breath is poisoned

repeating and constantly taking turns

till the moment

that some are forced or are being forced

to kiss the earth.)

The life struggle or rat race is a new national problem faced by all city dwellers of this country, iregardless of their race and religion. This social reality and challenge of city life are deemed as a necessity, a price that they have to pay for economic development, and this urban struggle is regarded as basic necessity to citizens that was described as critical for survival like udara (air) to our life:

Di sini, mengalah bererti pasrah

kerana setiap detik adalah perebutan 
antara perut kekalutan

dengan kemewahan atas injakan

hingga ada yang tidak punya ruang sama sekali

untuk bernafas lagi

pabila udaranya dicuri.

(Here, to lose means surrender

as every moment is rushed

between empty stomachs

and wealth from being stepped upon

till there are those with no space at all

to breathe again

whilst their air is stolen.)

Oleh kaki telah terpijak

kehidupan mesti diperjuangkan

biar bagaimana sesak.

biar bagaimana kotor

udara wajib direbut

untuk bernafas sesaat lagi.

(By the feet that have been stepped upon

life must be contested

no matter how dirty

air must be seized upon

so as to breathe another second.)

This poem won the Literary Award in 1979/80. After 30 years, its theme is still relevant and might be much more relevant to Singaporean today because its population has since growth rapidly. Compared to the earlier poems by Suratman and Mohd Latif which are intense in its emotion, this poem is more guarded in its expression and objective or rather detached observer in discussing common social problem issue.

\section{"Bagai Phoenix" (Like the Phoenix)}

Life struggle was also a focus by a woman poet named Rasial Halil. If Asmin discusses the theme of biological survival of the fittest in "Udara", Rasiah explores deeper into personal internal conflicts, that is rather heavy and challenging to face. Nevertheless, this internal conflict had been resolved with positive attitude and perspective, interpreted as God's test and as a 
learning and maturation process for her. In fact, the poet wants to rise from the ruins of miseries, following the action taken by the "Phoenix" in Greek Mythology:

Bahawa mereka yang seharusnya menyayang berwajah tidak peduli dan mendendam, rumah bukan lagi perlindungan, dan kasih sayang adalah kenangan.

Pelbagai cara Tuhan mengajar manusia tentang nilai dan erti dewasa dan bagai phoenix, aku bangkit dari segala duka. (For they who should have cared were indifferent and full of vengeance, a home is no longer a refuge, and love is a memory.

Varied are God's ways in teaching us the meaning and value of maturity and like the phoenix, I rise above all miseries.)

Rasiah, the third generation poet who received bilingual education in Singapore, has benefited from her exposure and knowledge of English literature to eloquently and effectively describe her personal experience and inner struggle. The choice of metaphors from classical western literature adds to the uniqueness of her poems in comparison to the other poems by her contemporaries.

\title{
"Di Tengah Alam" (In the Midst of the Universe)
}

From national issues, horizon of Malay poetry has widened to universal and global perspectives. The global position and challenge of Malays as a community and citizens of a small nation, was also the focus of Hadijah in her poem, "Di Tengah Alam" but she is looking it from international perspective. The poet reflects on her position as an individual from a minority community and small country, Singapore, who would make an impactful contribution internationally, and at the same time strongly upholds her religious belief:

\author{
Bagaimana dan bila \\ manusia seperti aku dari bangsa kerdil \\ di tengah negara kecil \\ akan lebih bererti dan disedari di peta dunia \\ dapat mengukir sebuah bekas di jalanan sejarah
}


menggantung sebutir kejora di dada cakerawala sambil mengecap keredhaan Allah!

(How and when will be possible a person like me from a minority community in a small country will be more significant and known by the world laying tracks in the pathways of history fastening the morning star in the universal heart while appreciating the bounty of Allah.)

The poem was written in 1983 and had won the Singapore Literary Award in 1986. It was a selected text for GCE 'A' level H2 and H3 papers (19 May 2005).

\section{"Seorang Bernama Manusia" (Someone Named Humanity)}

Nature has been an integral element of Malay poetry since the creation of Malay traditional poetry such as pantun and syair. Pantun, for example, uses nature as part of its symmetrical structure and foreshadow to convey its message. Hence, nature becomes the traditional element in Malay poetry, which is inherited by modern Malay poems, as shown by many works by first generation poets such as Noor SI and A. Ghani Hamid.

Noor SI in his poem, "Seorang Bernama Manusia" (Someone Named Humanity) uses the elements of nature such as rainbow, sky, birds etc. as parallelism to human life. Noor SI, A.Samad Said, A.S. Amin and M. Ghazali are a group of post-independent modern poets who experimenting using new genre of abstract poetry in 1960s, creating their own unique style of expression that was different from poems by poets of ASAS 50. They were known as "Penyair Kabur" (Abstract Poets) because previously Malay literary audience found it difficult to understand their poems and their message in comparison to works by earlier poets and before the Second World War.

(Apa yang aku pinta

panjatkanlah segala usia

ke puncak kepekaannya

bagai mergastua menghela sayapnya

kelkatu menenggangi lampu tua

memberi makna

dalam warna 
pelangi menujuhkalikan indahnya

di mana-mana.)

(What I entreat is

the stretching out of every life

to the zenith of sensitivity

like the birds pointing their wings

the night flies disturbing the antique lamp

giving meaning

in colours

of the rainbow with its sevenfold splendor .... everywhere.)

\section{"Terkocak" (Splashed)}

Another first generation poet who is still active to date, is A. Ghani Hamid, whose works are very close to nature as he subtlely uses elements of nature to express his personal feelings and views. His gentle voice is wisphering softly like calm waves, "bisikan ombak yang tenang". His poem, entitled "Terkocak" (Splash), is a best example of his expression that effectively combining his feeling with nature: ${ }^{6}$

Riak air tenang

menentang pepohonan di tebing

kuselami dasarnya

kutemui kesepian

kutemani sekitarnya

kutemui satu impian

(Rippling the still water

defying the trees on the bank

I dived to the bottom

and faced loneliness

I befriended the environs

and came upon a dream)

ketenangan seluas kolam

hijau airnya memanjang

kukucupi bayu lalu

terdengar sebuah lagu

kupetik nadanya

tersua rasa pilu. 
(The tranquility of the pond was spread wide

disturbed by a pack of grasshoppers

and a lone straggler at the edge of the water

I touched its wings

thus travellers' tale was whispered

whose ending was uncertain.)

A. Ghani Hamid is an early generation poet who received his education in both English and Malay streams of education, which enabled him to write well in both languages. This Tun Sri Lanang Award winner is also active in visual arts and this added the artistic strength to his poetry; hence, this multiplicity of art forms is manifested in his anthology of poetry, Petikan Rasa (2005).?

\section{"Puisi Syahdu" (A Poem of Beauty)}

Spiritual and religious issues cannot be separated from Malay poetry. Apart from the contemporary social problems, Malay poets also write about spiritual journey as subject of their works. Early experiment in this subject was undertaken by Djamal Tukimin, Noor Hidayat, A. Kadir Pandi, Eunos Asah -the second generation of writers. Djamal Tukimin formed a literary group, Grup Gelorasa, which attempted to make changes to literary expression and appreciation, different from the conventional ones done by poets of Asas $50 .^{8}$

Djamal Tukimin made the attempts to explore religious themes by combining it with nature and cultural elements. He also uses images of women in his poems, including in his religious poems. ${ }^{9}$ Djamal displayed a commitment to write about religious themes. However, it is difficult to select one poem that represents his strengths in religious poems. His poem, "Puisi Syahdu", is chosen because it touches on Islamic educational issues and its aesthetics in most natural, intimate manners and less deductic. The poem uses religious phrases and metaphors subtly and indirectly such as "dada langit" (the bossom of the sky), "setiap sujud" (each prostration). "tasbih-menasbih jari langit" (the sky fingers its worry beads), and "bulan sabit terbit di dadanya" (the crescent moon rises in her bosom):

Terbuka lempang dada langit. Kala ini matahari berkemas menyelam atas buih lautan kemanisan amat perasa dalam setiap sujud. 
(The bosom of the sky is clearly opened. At this time the man prepares to dive towards the sea's foam the sweetness is deeply tasted in each prostration)

\title{
MRT
}

Djamal's steps in spiritual journey is followed and even consolidated by another third generation poet, Johar Buang. In his hand, new spiritual and sufistic poems reaches prominence status. The revival of interest in Islam in South East Asian region was significant at the end of 1970s decade; hence, resulted to the emergence of interest in Islamic literature and its poetry. Among thousands of spiritual poems produced, Johar's poems are highly commendable, and his niche works in sufis genre even begin to have received regional attention and recognition. One of his best and unique poem is entitled MRT, which describes his spiritual journey in the physical or city contexts, using urban metaphors. This is rather a novel expression, in comparison to other sufis poems that tend to use metaphors from nature and cultural elements, such as sea and boat.

\author{
Kuturutkan gerabak ini berlalu \\ membawa matahatiku \\ dari Yishun ke Tanah Merah \\ dari Pasir Risk ke Raffles City \\ seperti aku pun berlari mencari-Mu \\ dari Safa ke Marwah \\ dari masyrik ke maghrib \\ dari alam malaikut ke alam jabarut
}

(I continue sitting in this moving coach

transporting my consciousness

from Yishun to tanah Merah

from Pasir Risk to Raffles City

Likewise I ran in search of you

from Safa to Marwah

from the east to the west

from the angelic to perfect dimensions)

This poem was awarded the Literay Award in 1993. 


\title{
“Tasik Rindu” (The Lake of Longing)
}

Nature and spiritual elements continue to attract the interest of younger generation of poets in Singapore who were active in 1980s, such as Isa Kamari. The third generation poets, despite enjoying higher education in comparison to the earlier generation, and are exposed to more varieties and cosmopolitant life of Singapore, are still motivated to preserve their religious and Malay cultural values. At the same time, they also displayed their inner most individual voices with refined, gentle and controlled manners.

Isa's poem is selected as it represents the latest mixed genre of Malay poetry, formed based on synthesis of various elements of tradition of MalayIslamic art, contemporary life that is influenced by new technology and existing popular culture. Isa Kamari dedicates his writing by documenting his spiritual experiences in poetry, attempting to revive Jawi script in his poetry books; and by composing songs based on his poems that would attract a wider audience. He attempts to integrate three forms of literary expressions -writing, reading and singing. His literary approaches and expression can be regarded as an innovative move from the conventional approach adopted by the previous Malay poets. Nevertheless, Isa's messages and values are still anchored on the religious values upheld by the Malay community. His traditional message is reflected not only in his poems with religious theme that recorded his pilgrimage experience in Mecca, but also in poem about his personal love, in which his value was conveyed subtly and gently. For example, his poem, "Tasik Rindu” (The Lake of Longing):

\author{
Sebutir embun kautitis \\ seumur hidupku \\ lemas ditenggelami \\ tasik rindu \\ (A dewdrop that you trickle \\ my entire life \\ will be drowned \\ in the lake of longing)
}

The poem was awarded Consolation Prize for the Singapore Literary Award in 1995. 


\section{CONCLUSIONS}

The 11 poems by 11 Singapore Malay poets of various generations that made their sensitive interpretations and insightful reflections on nature, race, religion and love, of their life and surrounding environment were discussed above. On the whole, their poems uphold ideal religious and cultural values of the Malay society, which have been long rooted in the community's life, and these values are creatively and subtly expressed by the poets employing their own individual poetic style of expression. These major themes and elements are interpreted and given subjective meanings; hence each poem serves as a additional colors and value to the poetry landscape of Singapore, which on the whole can be acknowledged as "the best literary achievement of a culture" over about 50 years. These selected poems have their own strengths in terms of aesthetic and cultural values and their creation contribute to development of a strong identity to Malay poetry in Singapore, and at the same time enriching its national literature and Malay literature in the region and beyond.

\section{NOTES}

1. Refer to "Revising the Literary Canon-Introduction" in Twentieth-Century Literary Criticism. Ed. Thomas J. Schoenberg Lawrence J. Trudeau. Vol. 114. Gale Cengage, 2006. eNotes.com. 2006. 20 Aug, 2010 http://www.enotes.com/twentieth-century-criticism/ revising-literary-canon/introduction.

2. See no of literary award winners (1974-1984) in Hadijah Rahmat (1987, 2004).

3. See the songs "Ini Nasi Yang Kusuap" composed by Nuradee and Karmin Abbas.

4. See Hadijah Rahmat, "Portrait of Nation- British Legacy on the Malay Settlement in Singapore" in Indonesia and the Malay World Volume 36, Number 106, November 2008, pp. 359-74(16).

5. Examples are Poetry Recital Competition in Pesta Bahasa dan Budaya 2008 in conjunction with Bulan Bahasa Melayu Singapura 2008, organized by Excecutive Committee of Fuchun Community Club, Marsiling \& Innova Junior College. See http://www. persadaku.org/pestabahasa08_sajakwajib_PBB08.htmuk

6. See article on A.Ghani Hamid by Hadijah Rahmat, "Nota: A.Ghani Hamid- Sebuah Alunan Ombak dan Kocakan Sepi di Pantai Seni" in Sastera dan Manusia Melayu Baru (1998:258-83) and interview by Hadijah with A.Ghani Hamid (1998:284-317).

7. "Petikan rasa" (Extracts of feelings)-A Collection of Poems and Paintings by A.Ghani Hamid. Published by Asas 50, 2005.

8. For further discussion on the Group Gelorasa, see Masuri SN, "Puisi Melayu di Singapura" in The Poetry of Singapore (1985:22-23); Hadijah, "Sastera Melayu Menjelang Abad ke 21-Cabaran, Kenyataan dan Harapan" in Sastera dan Manusia Melayu Baru (1998:178) 
and Djamal Tukimin, "Membumikan Akar Sejarah Sastera Melayu di Singapura" in Sejarah Tidak Pernah Luka Kita yang Berduka ( 2008:xvii-xx).

9. See his article, "Potret perempuan:Citra dan Proses Kreatif Sang Penyair" in ibid, 296310 .

\section{REFERENCES}

Abdul Ghani Hamid, 2005. Petikan Rasa-Extracts of Feelings, a collection of Poems and Paintings, Abdul Ghani Hamid. Singapore: Asas 50.

Djamal Tukimin, 2008. Sejarah Tidak Pernah Luka, Kita yang Berduka. Singapura: Pustaka Nasional.

Hadijah Rahmat, 1998. Sastera dan Manusia Melayu Baru. S'pore: Persatuan Wartawan Melayu Singapura.

Hadijah Rahmat, Dewani Abbas \& Azhar Ibrahim Alwee, 2004. Potret Diri Seorang Penyair. Siri Karya Anugerah Persuratan Singapure 1993-2001. Jilid 5. Singapore: Majlis Bahasa Melayu Singapura.

Isa Kamari, 2006. Ka'abah. Malaysia: Ameen Serve Holdings Sdn. Bhd.

Masuri SN, 1985. "Malay Poetry in Singapore" in The Poetry of Singapore, Anthology of Asean Literatures. Edited by Thumboo, Edwin, Wong Yoon Wah, Lee Tzu Peng, Masuri Salikun \& Arasu, V.T. Published under sponsorship of The ASEAN Committee on Culture and Information.

Kirpal Singh \& Wong Yoon Wah, 2000. Rhythms- a Singaporean Millennial anthology of Poetry. Singapore: National Arts Council. 